\title{
Blood Circulation
}

National Cancer Institute

\section{Source}

National Cancer Institute. Blood Circulation. NCI Thesaurus. Code C16353.

The movement of blood to and from the heart and to the rest of the body's organs, tissues, and cells through the network of arteries, veins, and capillaries. $(\mathrm{NCl})$ 